J. Management and Humanity Research

Vol. 1, 2019, 1-10

ISSN:2582-7766 (online)

Published on 18 June 2019

www.researchmathsci.org

DOI: http://dx.doi.org/10.22457/jmhr.v1a01101

Journal of

Management and

Humanity Research

\title{
Determinants of Consumer's Online Purchase Behavior in Zimbabwe
}

\author{
Louise Tendai Matatu \\ School of Economics and Management \\ Chongqing University of Posts and Telecommunications \\ Chongqing - 400065, Chongqing, China. E-mail: 451417524@qq.com
}

Received 1 May 2019; accepted 10 June 2019

Abstract. This study investigated online consumer behaviour among Zimbabweans living in Harare. The results show that Attitude has a positive effect on Purchase Intention and Attitude has a positive effect on behaviour. The results also show that Purchase Intention positively affects the relationship between Attitude and Behaviour. Meanwhile Facilitating Conditions positively moderated the relationship between Purchase Intention and Behaviour. Based on the research findings and conclusions, a number of recommendations and areas of future research are suggested.

Keywords: Online shopping; attitude; purchase intention; facilitation

AMS Mathematics Subject Classification (2010): 62P25

\section{Introduction}

The use of the internet has reshaped organizations' way of thinking about strategies, gathering information and process redesign. Many businesses around the world are adopting and introducing e-commerce processes in their business activities. Some firms conduct their businesses purely by cyberspace. More people are turning to online shopping for their needs as online shopping grows in popularity. As competition in ecommerce is intensifying, it is becoming more important for online retailers to understand the online shopping behaviour of their consumers.

Online shopping is a form of e-commerce which enables consumers to purchase goods and/or services over the internet, via a web browser or a mobile application. There are advantages of online shopping from the consumers' perspective. Consumers are able to make better buying decisions because of increased opportunities for comparing prices with alternative products (Jusoh \& Ling, 2012). Consumers are also not restricted by opening and closing times of physical stores and their geographical locations as they can shop anytime and anywhere over the internet.

According to a household survey carried out by the Zimbabwe National Statistics Agency (ZIMSTAT) and the Postal and Telecommunications Regulatory Authority (POTRAZ) in 2014, internet access in urban areas is $82 \%$. The internet is accessed mainly through mobile devices. Online shopping in recent years has been growing due to retailers such as Zimall and Ownai; the introduction of Hammer and Tongues' online 


\section{Louise Tendai Matatu}

store; and the food delivery service, Munch. More and more organizations in Zimbabwe are using the internet to reach their clients.

While there are studies that have focused on online shopping behaviour on a global scale, there is still a need for examining online shopping behaviour in Zimbabwe due to the cultural norms and economic situation. Zimbabwe is currently experiencing a liquidity crunch and this has forced consumers, especially those in the urban areas to adopt e-commerce. The liquidity crunch also forced companies to quickly implement their e-commerce strategies and integrate online payment platforms into their processes. These factors would affect attitude and purchase intention of consumers in Zimbabwe.

Much of the research on e-commerce in Zimbabwe has focused on businesses, and very few have focused on the consumers and their behaviour towards online shopping. This research intends to fill in that gap in the literature.

The rate of online shopping in Zimbabwe has increased. In spite of the benefits of online shopping that can be achieved for companies and consumers, the actual use is still low in Zimbabwe. According to a household survey carried out by the Zimbabwe National Statistics Agency (ZIMSTAT) and the Postal and Telecommunications Regulatory Authority (POTRAZ) in 2014 only $1 \%$ of the individuals surveyed had made a purchase online. Does this suggest the lack of willingness to shop, or does it suggest that unfamiliarity with internet shopping? When it comes to understanding Zimbabwean consumers' perspective on online shopping, it is unclear.

Consumers' acceptance of online shopping in Zimbabwe is still in its developing stage and little is known about the attitude towards online shopping and online consumer behaviour.

\section{Literature review}

\subsection{Purchase intention}

Purchase intention is the most immediate predictor of behaviour and results from underlying attitudes and subjective norms. Online shopping intention does not always equal to actual purchase behaviour. Hsu \& Bayarsaikhan (2012) stated that "intention represents the strength of an individual's plan to perform a specific behaviour". Purchase intention is an indicator of how hard a consumer is willing to try to make the purchase (Aldmour \& Sarayrah, 2016). The stronger the purchase intention, the more likely a person will make an online purchase. Lim et al. (2015) stated that attitude influences customer's evaluation and judgment, and would affect a consumer's perception. A positive attitude towards using the Internet creates a greater intention to use the Internet, which increases the use of the Internet to purchase goods and services (Amoroso \& Hunsinger, 2009).

\subsection{Attitude}

Attitude could be defined as the extent to which a person considers online shopping a good idea and likes online shopping (Vijayasarathy, 2003). Fishbein and Ajzen (1975) classified Attitude into two constructs: attitude toward the object and attitude toward the behaviour. Attitude is a general orientation towards a behaviour based on a variety of beliefs and emotions. It is determined by identifying a set of relevant beliefs, measuring the strength, or certainty of these beliefs, and measuring their evaluation as well. Attitude is specific to performing a particular behaviour. To determine attitude, belief strength and 
Determinants of consumer's online purchase behavior in Zimbabwe

evaluation are empirically weighted for a specific behaviour before they are added together. Consumers attitude towards online shopping refers to their psychological state in terms of making purchases over the internet" (Dani, 2017).

"Attitudes serve as the bridge between consumers' background characteristics and the consumption that satisfies their needs. Attitudes describe a person's relatively consistent evaluations, feelings and tendencies towards an object or idea. Attitudes pit people into a frame of mind for liking or disliking things, for moving toward or away from them" (Wu, 2003). Attitudes are developed from personal experiences, learning with reality and from both direct and indirect experiences in life (Wu, 2003). A consumer with a positive attitude towards online shopping will most likely have greater intentions to shop online, and will most likely shop online. Attitudes vary among individuals because of different environment, culture or society (Shanthi and Kannaiah, 2015).

Trust influences a consumer's attitude toward online shopping. Trust can be part of the attitude to attract or convince the consumer to shop online (Hasbullah et al., 2016). Trust refers to the consumer perception towards online retailer's behaviour based on their ability, kindness and honesty (Cheng \& Yee, 2014). Cheng \& Yee (2014) also state that building the foundation for trust is essential in order to improve the relationship between e-commerce providers and customers. An online transaction is perceived to be riskier, and the sense of trust can reduce the fear of uncertainty.

\subsection{Facilitating conditions}

Facilitating conditions represent a person's situation and are important determinants of online shopping behavioural intention. These factors include access to the internet and the finances to shop online. Other facilitating conditions include the availability of reliable payment systems.

Looking at the role that facilitating conditions play in influencing a person's behaviour to shop, this variable is included into the Theory of Planned Behaviour framework to examine if it moderates the relationship between intention and behaviour. I consider this as a gap in literature because a person can have the intention, but the facilitating conditions might influence the final behaviour. Also, research focuses on facilitating conditions influencing intention or moderating the relationship between intention and subjective norms and attitude (Salisu et al., 2017).

Lack of resources and knowledge have a negative effect on online shopping. The high cost of accessing the internet affects online shopping behaviour. Chivasa \& Hurasha (2016) and Batanai, Denhere and Mawere (2015) found that high internet charges have a negative on e-commerce. This leads to a negative view of online shopping which reduces online shopping behaviour. Batanai Denhrere and Mawere (2015) also found out that lack of knowledge about e-commerce can affect the use of the internet to make purchases.

\section{Research model}

Based on the literature review, the following research model was created. 


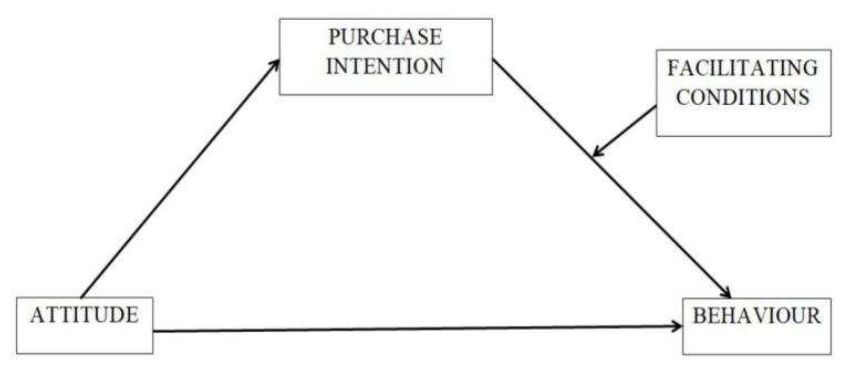

Figure 1: Research Model

\subsection{Hypotheses}

Based on the literature review and research model above, the following hypotheses were formed:

H1: A consumer's attitude towards online shopping positively influences online shopping behaviour.

H2: A consumer's attitude towards online shopping positively influences the intention to purchase online.

H3: Purchase intention mediates the relationship between attitude towards online shopping and online shopping behavior

H4: Facilitating conditions moderates the relationship between intention to purchase and online shopping behaviour.

\subsection{Population and sampling}

The population in this study is comprised of those with access to the internet in Harare, Zimbabwe. For the research objectives to be met, the respondents were chosen using a non-probability sampling method. Non-probability sampling focuses on sampling techniques where the respondents chosen for the research are based on the judgment of the researcher. Crouch (2012) recommends that minimum sample size for quantitative shopper surveys are between 300 and 500 respondents.

To collect the data required for this study, purposive random sampling was used to select the participants. This technique allowed the researcher to use her judgment to select the respondents that would be able to provide the data suitable for the study. The elements used to select the participants in this study are the geographical location of the respondents and the ability to access the internet by the respondents. Hence an online survey was used to make sure that the respondents have access to the internet.

\subsection{Data collection methods}

For the survey, a questionnaire was designed with questions adapted from Kirui (2016). A questionnaire was suitable for this data because it is useful for collecting quantitative 
Determinants of consumer's online purchase behavior in Zimbabwe

data, organize the questions and get replies without having to talk to the respondents (Walliman, 2011). Walliman (2011) also states that the other advantages of the questionnaire are that it can be structured and it is cheap and easy to administer to a large number of respondents. These advantages helped the researcher to collect the data. The questionnaire was uploaded online and the link sent to as many people as possible, who responded and sent to more people to respond. A total of 317 people responded to the questionnaire.

Table 1: Research variables and measurements

\begin{tabular}{|c|c|c|c|}
\hline Construct & Variable Type & Scale & Indicators \\
\hline \multirow{8}{*}{ Attitude } & \multirow{8}{*}{ Independent } & \multirow{8}{*}{ Ordinal } & $\begin{array}{l}\text { ATT-1: Shopping online saves me time } \\
\text { when purchasing goods or services. }\end{array}$ \\
\hline & & & $\begin{array}{l}\text { ATT-2: Goods can be easily compared in } \\
\text { online shopping. }\end{array}$ \\
\hline & & & $\begin{array}{l}\text { ATT-3: I find online shopping in Zimbabwe } \\
\text { understandable. }\end{array}$ \\
\hline & & & $\begin{array}{l}\text { ATT-4: Buying goods and services online is } \\
\text { easy to do. }\end{array}$ \\
\hline & & & $\begin{array}{l}\text { ATT-5: Online shopping of goods and } \\
\text { services is safe. }\end{array}$ \\
\hline & & & $\begin{array}{l}\text { ATT-6: Generally, I find online stores } \\
\text { trustworthy. }\end{array}$ \\
\hline & & & $\begin{array}{l}\text { ATT-7: Online shopping in Zimbabwe is a } \\
\text { good idea. }\end{array}$ \\
\hline & & & $\begin{array}{l}\text { ATT-8: I enjoy shopping for goods and } \\
\text { services online. }\end{array}$ \\
\hline \multirow{3}{*}{$\begin{array}{l}\text { Purchase } \\
\text { Intention }\end{array}$} & \multirow{3}{*}{ Independent } & \multirow{3}{*}{ Ordinal } & $\begin{array}{l}\text { PI-1: I intend to purchase goods and } \\
\text { services online in the near future. }\end{array}$ \\
\hline & & & $\begin{array}{l}\text { PI-2: I will purchase goods or services } \\
\text { online in the near future. }\end{array}$ \\
\hline & & & $\begin{array}{l}\text { PI-3: I predict I will purchase goods or } \\
\text { services within the next month. }\end{array}$ \\
\hline \multirow{3}{*}{$\begin{array}{l}\text { Facilitating } \\
\text { Conditions }\end{array}$} & \multirow{3}{*}{ Independent } & \multirow{3}{*}{ Ordinal } & $\begin{array}{l}\text { FC-1: I have the resources needed to do } \\
\text { online shopping. }\end{array}$ \\
\hline & & & $\begin{array}{l}\text { FC-2: I have the knowledge needed to } \\
\text { purchase goods and/or services online. }\end{array}$ \\
\hline & & & $\begin{array}{l}\text { FC-3: Online shopping is compatible with } \\
\text { other technologies I use. }\end{array}$ \\
\hline \multirow{3}{*}{ Behaviour } & \multirow{3}{*}{ Dependent } & \multirow{3}{*}{ Ordinal } & $\begin{array}{l}\text { B-1: I buy goods or services using the } \\
\text { internet often. }\end{array}$ \\
\hline & & & $\begin{array}{l}\text { B-2: I prefer buying online rather than going } \\
\text { to a physical store. }\end{array}$ \\
\hline & & & $\begin{array}{l}\text { B-3: I am free to purchase any product or } \\
\text { service online. }\end{array}$ \\
\hline
\end{tabular}




\section{Louise Tendai Matatu}

\section{Data analysis and conclusion}

Regression Analysis is carried out by SPSS. The dependent variable is Behaviour, and the independent variable is Attitude. Purchase Intention is the mediating variable whilst facilitating conditions is a moderating variable. Age, approximate monthly income and employment status were chosen as control variables. The results are presented in three sections. The first section shows the direct impacts of the independent variables and the control variables on the independent variable. The second section shows the mediated effect of purchase intention on the relationship between attitude and behaviour. The third section shows the moderating effect of facilitating conditions on the relationship between purchase intention and behaviour.

\subsection{Direct impacts on behaviour}

In this section, the direct impact of each independent variable and the control variables to the dependent variable is tested. The impact of both independent variables together on the dependent variable is also tested. The table below shows the results of the regressions.

Table 2: Direct impacts on behaviour

\begin{tabular}{|c|c|c|c|}
\hline Variable & Model 1 & Model 2 & Model 3 \\
\hline Age & -0.013 & -0.060 & 0.000 \\
\hline Income & $0.126^{* *}$ & $0.159^{* *}$ & 0.079 \\
\hline Employment status & -0.063 & -0.026 & -0.029 \\
\hline Attidute & $0.745^{* *}$ & - & $0.481^{* *}$ \\
\hline Purchase Intention & - & $0.593^{* *}$ & $0.317^{* *}$ \\
\hline R2 & 0.595 & 0.566 & 0.646 \\
\hline
\end{tabular}

Note: $* \mathrm{P}<0.05, * * \mathrm{P}<0.01$

Each model tested is statistically significant because the prob (F-statistic) $=0.000$, which is less than 0.05 . The control variables do not make a statistically significant contribution to online shopping behaviour as $\mathrm{P}$ is greater than 0.05 . Attitude represents personal feelings towards online shopping. A positive attitude towards online shopping behaviour leads to more online shopping purchases. Attitude is significant $(\mathrm{P}<0.01)$. This confirms the research hypothesis that attitude has a positive effect on online shopping behaviour. A positive attitude is a requirement for consumers to purchase goods and services online. A negative attitude towards online shopping would discourage consumers from making purchases online.

Purchase intention represents the willingness to buy goods or services online. This variable is significant $(\mathrm{P}<0.01)$. This confirms the research hypothesis that purchase intention has a positive effect on online shopping behaviour. The more a consumer is willing to make a purchase online, the, more likely that the consumer will make a purchase.

\subsection{Mediation test}

This section is to test the mediation effect of purchase intention on the relationship between attitude and online shopping behaviour. The first model shows the effect of attitude on behaviour. The second model shows both the effect of attitude and purchase intention on behaviour and the third model shows the effect of attitude on purchase 
Determinants of consumer's online purchase behavior in Zimbabwe

intention. Each model tested is statistically significant because the prob (F-statistic) = 0.000 , which is less than 0.05 . Mediation is said to occur when the following conditions are met:

(1)The independent variable significantly affects the mediating variable;

(2)The independent variable significantly affects the dependent variable without the mediating variable

(3)The mediating variable has a significant unique effect on the dependent variable

(4)The effect of the independent variable on the dependent variable shrinks upon the addition of the mediator.

The table below shows the results of the mediation.

Table 3: Mediation test

\begin{tabular}{|c|c|c|c|}
\hline \multirow{2}{*}{} & \multicolumn{2}{|c|}{$\begin{array}{c}\text { Dependent Variable: } \\
\text { Behaviour }\end{array}$} & $\begin{array}{c}\text { Dependent Variable: } \\
\text { Purchase Intetnion }\end{array}$ \\
\hline Variable & Model 1 & Model 2 & Model 3 \\
\hline Age & -0.013 & 0.000 & -0.042 \\
\hline Income & $0.126^{* *}$ & 0.079 & $0.148^{* *}$ \\
\hline Employment status & -0.063 & -0.029 & $-0.106^{*}$ \\
\hline Attitude & $0.745^{* *}$ & $0.481^{* *}$ & $0.832^{* *}$ \\
\hline Purchase Intention & - & $0.317^{* *}$ & - \\
\hline $\mathrm{R}^{2}$ & 0.595 & 0.646 & 0.602 \\
\hline
\end{tabular}

Note:*P<0.05, **P<0.01

As shown in the table above, attitude affects the mediating variable, purchase intention significantly, with a coefficient of $0.832(\mathrm{P}<0.01)$. Attitude affects behaviour significantly $(\mathrm{P}<0.01)$ without the mediating variable in the model. Purchase intention also has a significant effect on online shopping behaviour as shown in Table 3. When the mediating variable is added to the regression model, the effect of attitude on online shopping behaviour decreases to $0.481(\mathrm{P}<0.01)$. This supports the hypothesis that purchase intention mediates the relationship between attitude towards online shopping and online shopping behaviour. Consumers need to have a positive attitude towards online shopping as well as the intention for them to be more willing to purchase goods and services online.

\subsection{Moderation test}

This section shows the result of moderated mediation. Facilitating conditions was added to the model before performing the regression. Regression coefficient of interaction variable of purchase intention and facilitating conditions show that its value is not significant (the sig. value is larger than 0.05), demonstrating that the perception of facilitating conditions by a consumer does not affect the relationship between purchase intention and online shopping behaviour. Therefore, the moderation effect is not significant and the hypothesis 4 is not supported. 
Louise Tendai Matatu

Table 4: Moderation test

\begin{tabular}{|c|c|}
\hline Variable & Model \\
\hline Age & 0.010 \\
\hline Income & 0.050 \\
\hline Employment status & -0.027 \\
\hline Attitude & $0.350^{* *}$ \\
\hline Purchase Intention & $0.240^{* *}$ \\
\hline Facilitating Conditions & $0.237^{* *}$ \\
\hline Purchase intention x facilitating conditions & 0.057 \\
\hline R2 & 0.664 \\
\hline
\end{tabular}

Note: $* \mathrm{P}<0.05, * * \mathrm{P}<0.01$

Based on the above regression results, we can obtain that the established hypothesis were supported except $\mathrm{H} 4$. The summary is provided in table 5 .

Table 5: Summary of hypothesis results

\begin{tabular}{|l|c|}
\hline \multicolumn{1}{|c|}{ Hypothesis } & Result \\
\hline $\begin{array}{l}\text { H1: A consumer's attitude towards online shopping positively influences } \\
\text { online shopping behaviour. }\end{array}$ & Supported \\
\hline $\begin{array}{l}\text { H2: A consumer's attitude towards online shopping positively influences } \\
\text { the intention to purchase online. }\end{array}$ & Supported \\
\hline $\begin{array}{l}\text { H3: Purchase intention positively mediates the relationship between } \\
\text { attitude towards online shopping and online shopping behaviour }\end{array}$ & Supported \\
\hline $\begin{array}{l}\text { H4: Facilitating conditions positively moderates the relationship between } \\
\text { intention to purchase and online shopping behaviour. }\end{array}$ & Not \\
\hline
\end{tabular}

\section{Discussion and summary}

Based on the findings demonstrated in this research, we propose that there are three optional strategies that organizations in Zimbabwe can adopt to ensure that consumers have a positive attitude towards online shopping and to make sure that more and more consumers take advantage of online shopping.

First, Companies should be trustworthy and ensure that the correct goods purchased are shipped to their consumers within the specified time. The quality of the goods shipped should always match the expectations of the consumer. Trustworthiness increases the positiveness of the attitude towards online shopping. To be trustworthy, 
Determinants of consumer's online purchase behavior in Zimbabwe

companies need to design processes that confirm that the right goods and services are sent to the correct customer. Sellers should ensure "what you see is what you get". This increases purchase intention and in turn, online shopping behaviour.

Second, Businesses should create user-friendly interfaces on their websites and mobile applications that make it easy to navigate the website or mobile application. A user-friendly interface increases the usefulness as the consumer would not need a lot of effort to navigate and make a purchase online, which will then result in a positive attitude and increase purchase intention.

Third, Have good customer relations with existing and potential customers. This leads to a good attitude towards online shopping. Consumers are more likely to make an online purchase. Having patient and professional customer care staff would make organizations competitive and result in more sales.

\section{REFERENCES}

1. F.Aldmour and I.Sarayrah, An investigation of factors influencing consumer's intention to use online shopping: an empirical study in South Jordan, Journal of Internet Banking and Commerce, 34(2016) 45-65.

2. D.L.Amoroso, and D.S.Hunsinger, Understanding consumers' acceptance of online purchasing, Journal of Information Technology Management, 20(1)(2009) 15 - 41.

3. J.Batanai, P.T.Denhere and T.Mawere, The role of e-commerce in resuscitating the economy of Zimbabwe, International Journal of Management and Business Studies, 5(2)(2015) 44-48.

4. B.L.Cheng and S.W.Yee, Factors Influencing Consumers' Online Purchase Intention: A Study among University Students in Malaysia, International Journal of Liberal Arts and Social Science, 2(8)(2014) 121-133.

5. S.Chivasa and C.Hurasha, Small and Medium Enterprises' (SMEs) Adoption and Usage of E-Commerce: A Probit Modelling, International Journal of Economics, Commerce and Management, 4 (3)(2016) 218-226.

6. S.Crouch and M.Housden, Marketing Research for Managers, Routledge, (2012).

7. N.J.Dani, A Study on Consumers' Attitude towards Online Shopping, International Journal of Research in Management and Business Studies, 4 (3)(2017) 42-46.

8. M.Fishbein and I.Ajzen, Belief, Attitude, Intention and Behaviour: An introduction to Theory and Research, Addison-Wesley: Boston, (1975).

9. S.H.Hsu and B.E.Bayarsaikhan, Factors Influencing on Online Shopping Attitude and Intention on Mongolian Consumers, The Journal of International Management Studies, 7(2)(2012)167-176.

10. N.A.Hasbullah, et al., The Relationship of Attitude, Subjective Norm and Website Usability on Consumer Intention to Purchase Online: An Evidence of Malaysian Youth, 7th International Economics \& Business Management Conference, (2016).

11. Z.M.Jusoh and G.H.Ling, Factors Influencing Consumer's Attitude towards ECommerce Purchases through Online Shopping, International Journal of Humanities and Social Science, 2(4)(2012) 33-45.

12. A.K.Kirui, A Study of Consumer Behaviour towards Online Shopping in Kenya: Case of Nairobi County, International Journal of Humanities and Social Science, 5(4)(2016) 35-45. 


\section{Louise Tendai Matatu}

13. Y.J.Lim, et al., The Mediating Effect of Consumers' Purchase Intention: A Perspective of Online Shopping Behaviour among Generation Y, Journal of Marketing and Consumer Research, 18(2015)101-112.

14. M.K.Salisu, et al., Examining the Moderating Role of Perceived Lack of Facilitating Conditions on Household Recycling Intention in Kano, Nigeria, Recycling, 2(18)(2017) 44-55.

15. R.Shanthi and D.Kannaiah, Consumers' Perception on Online Shopping, Journal of Marketing and Consumer Research, 13(2015) 14-20.

16. S.Taylor and P.Todd, Decomposition and Crossover Effects in the Theory of Planned Behavior: A Study of Consumer Adoption Intentions, International Journal of Research in Marketing, 12(2)(1995)137-155.

17. L.R.Vijayasarathy, Predicting Consumer Intentions to Use Online Shopping: The Case for an Augmented Technology Acceptance Model, Information \& Management, 41(6)(2003) 747-762.

18. N.Walliman, Research Methods: The Basics, London: Routledge, (2011).

19. S.I.Wu, The Relationship between Consumer Characteristics and Attitude Towards Online Shopping, Marketing Intelligence \& Planning, 21(1)(2003) 37-44. 